\title{
Ovine fetal testis stage-specific sensitivity to environmental chemical mixtures
}

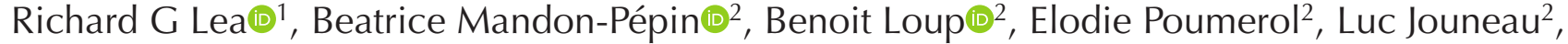 \\ Biola F Egbowon ${ }^{1}$, Adelle Bowden ${ }^{1}$, Corinne Cotinot ${ }^{2}$, Laura Purdie ${ }^{1}$, Zulin Zhang ${ }^{3}$, \\ Paul A Fowler ${ }^{4}$ and Kevin D Sinclairi ${ }^{1}$ \\ ${ }^{1}$ University of Nottingham, Sutton Bonington Campus, Loughborough, UK, ${ }^{2}$ Université Paris-Saclay, UVSQ, INRAE, \\ BREED, Jouy-en-Josas, France, ${ }^{3} J a m e s$ Hutton Institute, Craigebuckler, Aberdeen, UK and ${ }^{4}$ University of Aberdeen, \\ Institute of Medical Sciences, Aberdeen, UK
}

Correspondence should be addressed to R G Lea; Email: richard.lea@nottingham.ac.uk

\begin{abstract}
Exposure of the fetal testis to numerous individual environmental chemicals (ECs) is frequently associated with dysregulated development, leading to impaired adult reproductive competence. However, 'real-life' exposure involves complex mixtures of ECs. Here we test the consequences, for the male fetus, of exposing pregnant ewes to EC mixtures derived from pastures treated with biosolids fertiliser (processed human sewage). Fetal testes from continuously exposed ewes were either unaffected at day 80 or exhibited a reduced area of testis immunostained for CYP17A1 protein at day 140. Fetal testes from day 140 pregnant ewes that were exposed transiently for 80-day periods during early (0-80 days), mid (30-110 days), or late (60-140 days) pregnancy had fewer Sertoli cells and reduced testicular area stained for CYP17A1. Male fetuses from ewes exposed during late pregnancy also exhibited reduced fetal body, adrenal and testis mass, anogenital distance, and lowered testosterone; collectively indicative of an antiandrogenic effect. Exposure limited to early gestation induced more testis transcriptome changes than observed for continuously exposed day 140 fetuses. These data suggest that a short period of EC exposure does not allow sufficient time for the testis to adapt. Consequently, testicular transcriptomic changes induced during the first 80 days of gestation may equate with phenotypic effects observed at day 140. In contrast, relatively fewer changes in the testis transcriptome in fetuses exposed continuously to ECs throughout gestation are associated with less severe consequences. Unless corrected by or during puberty, these differential effects would predictably have adverse outcomes for adult testicular function and fertility.

Reproduction (2022) 163 119-131
\end{abstract}

\section{Introduction}

Exposure to environmental pollutants during fetal, neonatal, and/or adult life is associated with adverse effects on male reproductive development and function (Sumner et al. 2020). Chemical release into the environment has increased markedly since the 1950s ( $>140,000$ chemicals) and this is associated with adverse temporal trends in human male reproductive health (Landrigan 2017). Meta-analyses now confirm that human sperm counts have declined by $50 \%$ over 70 years (Carlsen et al. 1992, Swan et al. 2000, Levine et al. 2017). Concomitant with these temporal changes, incidences of testicular cancer in young adults and malformations in male newborns (cryptorchidism and hypospadias) have also increased (Skakkebaek et al. 2016, Park et al. 2018). In support of an environmental cause, the occupational exposures of mothers to chemical pollutants have been associated with reduced semen quality in their offspring (Istvan et al. 2021). Exposure studies in sheep, dogs, and rodents are similarly indicative of pollutant effects on male reproductive health (Paul et al. 2005, Salian et al. 2011, Sumner et al. 2020). In addition, animal model studies indicate that male reproductive disorders are linked and originate following exposure during fetal life (Skakkebaek et al. 2001, WohlfahrtVeje et al. 2009). The majority of studies have focussed on single chemicals and, in some cases, at doses much higher than environmental exposure levels. Since environmental pollutants constitute a complex mixture, extrapolating from single chemical effects to real-life exposure is problematic.

To investigate real-world exposures, pregnant ewes are grazed on pastures treated with biosolids fertiliser generated from processed human sewage sludge. This is recognised agricultural practice worldwide and the fertiliser contains chemical pollutants which, in combination, represent exposure in humans. A wide range of chemical types have been detected in biosolids and in maternal and fetal livers collected from ewes 
that had grazed-treated pastures (Lea et al. 2016, Viguie et al. 2020). Although directly equating changes in liver chemical load with concentrations in the soil are problematic, exposure has been linked to an increased chemical burden in maternal livers and developmental effects in the mid-gestation male fetal testis. These include reduced numbers of gonocytes, Sertoli and Leydig cells, and a parallel reduction in fetal inhibin A and testosterone (Paul et al. 2005). Extending gestational exposure to day 1 neonates and to 7 months in offspring reduced germ cell numbers and induced Sertoli cellonly tubules in cohorts of neonatal and adult animals. In adults, reduced Sertoli cell numbers were also reported (Bellingham et al. 2012, Elcombe et al. 2021). Biosolids exposure is also associated with adverse effects on the fetal ovary, thyroid, and hypothalamo-pituitary axis as well as in the adult liver (Fowler et al. 2008, Bellingham et al. 2009, 2010, Hombach-Klonisch et al. 2013, Lea et al. 2016, Filis et al. 2019). Taken together, a conclusion that exposure to chemicals not only impacts the developing fetus but also has longer-term consequences for adult wellbeing is inescapable.

We previously reported that exposing ewes for overlapping 80-day periods that encompass early ( $0-80$ days), mid ( $30-110$ days), and late ( $60-140$ days) gestation induce differential and adverse changes in the fetal ovary (Lea et al. 2016). Since these 80-day periods also encompass critical developmental stages in the developing fetal testis (Fig. 1), the current study was designed to determine the effects of transient and consistent exposures on the developing male. Given the continuum of testis development, days 0,30 , and 60 fetal testes will have different cellular compositions largely reflecting periods of Sertoli and Leydig cell proliferation. Since this depends on gestational age, we postulated that the 80-day exposure periods will differentially impact developmental processes including Sertoli and Leydig cell proliferation. Our primary morphological studies therefore focussed on these cell types. Here, we report that exposure during the first third of gestation induced transcriptomic changes measurable in the late gestation fetal testis and exposure in the last third of gestation induced broader phenotypic changes in the male fetus.

\section{Methods}

\section{Animals, treatment groups, and tissue collection}

All animal experimental protocols were approved by the James Hutton Institute's Local Ethical Committee and licensed by the United Kingdom's Animals Scientific Procedures Act 1986 (Project license: 60/3356). All procedures were performed in accordance with relevant guidelines and regulations.

The treatment of pastures with biosolids and grazing of sheep were carried out as previously described (Lea et al. 2016). In brief, pastures were fertilised with a single treatment of thermally dried sewage sludge (2.25 metric tons of dry matter/ha; treated: T) or with inorganic fertiliser balanced for

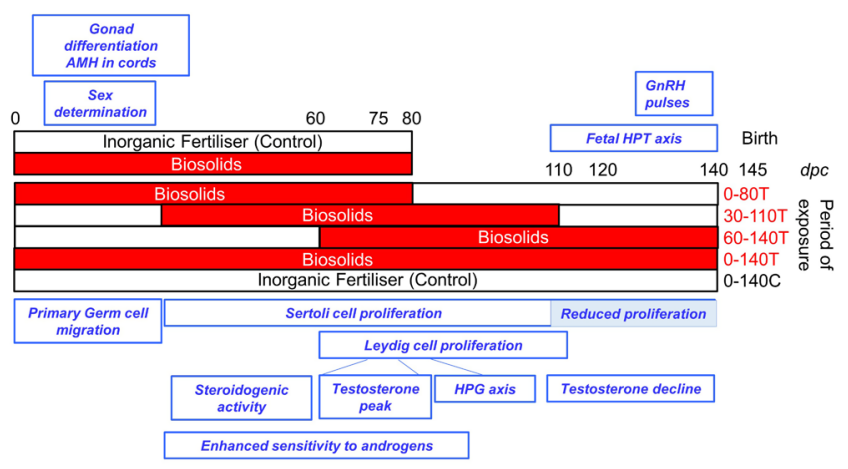

Figure 1 Experimental design to investigate the effects of biosolids exposure on the fetal testis. Pregnant ewes were sacrificed at day 80 ( 2 cohorts) or day 140 (5 cohorts) of gestation. In the day 80 group, ewes were exposed to biosolids-treated pastures or pastures fertilised with inorganic fertiliser. In pregnant ewes maintained to day 140 , exposure to biosolids-treated pastures occurred from: days 0 to 140 (0-140T, continuous exposure), days 0 to 80 ( $0-80 \mathrm{~T}$, early exposure), days 30 to 110 (30-110T, mid-exposure), and days 60 to 140

(60-140T, late exposure). Control group pregnant ewes (C) were maintained on pastures treated with inorganic fertiliser from days 0 to 140 of gestation (0-140C). For array transcriptomics, 0-80T, 0-140T, and $0-140 \mathrm{C}$ groups were used. The main events of differentiation in the fetal testis are described in the blue rectangles. Key references: Sertoli cell proliferation: (Hochereau-de Reviers et al. 1995), steroidogenic activity/testosterone: (Pomerantz \& Nalbandov 1975, Quirke et al. 2001), fetal HPT function: (Mesiano et al. 1991, Roselli et al. 2016).

nitrogen (225 kg/ha/year; control: C). Experimental animals were maintained on either $\mathrm{C}$ or $\mathrm{T}$ pastures. Mature Texel ewes were allocated to one of seven treatment groups (Fig. 1) randomly keeping body condition score as consistent as possible. Although initial group size comprised approximately 14 pregnant ewes, the results reported concern only those carrying at least 1 male fetus.

Two groups were either exposed to biosolid treated or control pastures from mating to sacrification at mid-gestation (day 80). The remaining five groups were all maintained to sacrification at late gestation (day 140) and comprised one group grazed on C pastures throughout (0-140C), one group exposed to $T$ pastures throughout (0-140T), and three transiently exposed groups where exposure was limited to 80-day periods during early (0-80 days), mid (30-110 days), or late (60-140 days) gestation (Fig. 1). Pregnancies were established by mating ewes with Texel rams at the second synchronized estrus following the withdrawal of progestagen sponges (chronolone, $30 \mathrm{mg}$; Intervet, Cambridge, UK). Pregnant ewes were either maintained on $\mathrm{T}$ pastures or transferred between $\mathrm{C}$ and $\mathrm{T}$ pastures (and back again), as appropriate. All ewes were habituated to being moved between pastures, thus minimising stress. When pregnant ewes were moved, they were maintained on a separate pasture for a few days to minimise $\mathrm{C}$ pasture contamination by faeces and urine.

All pregnant ewes were euthanised according to Schedule 1 protocols (UKAnimals Scientific Procedures Act, 1986). Samples and data (organ weights, etc.) were collected and processed according to our standard protocols (Bellingham et al. 2013, 
Lea et al. 2016). In brief, fetal anogenital distance (AGD) and selected organ weights were measured and recorded. One testis per fetus was analysed for histology and the second for transcriptomic studies. Testes were Bouin's fixed for histological analysis or snap-frozen in liquid nitrogen and stored at $-80^{\circ} \mathrm{C}$ for RNA extraction. Maternal and fetal liver sample processing and chemical measurements were reported by (Lea et al. 2016).

\section{Testis immunohistochemistry and histomorphology}

Bouin's-fixed testes were processed for immunohistochemistry: Sertoli cells (anti-Mullerian hormone; AMH), Leydig cells (steroidogenic enzymes: CYP11A1, CYP17A1), and proliferation (Ki67). Established immunohistochemistry protocols were applied (Paul et al. 2005, Andrade et al. 2013) including epitope retrieval (microwaving: $3 \times 5 \mathrm{~min}$ in 0.01 $M$ citrate buffer $\mathrm{pH}$ 6.0) and application of the Vectastain $A B C$ universal Elite kit (2B Scientific Ltd, Stonesfield, UK) protocol. Tissue sections were incubated with primary antibodies for $1 \mathrm{~h}$ at room temperature: (a) polyclonal goat AMH (Santa Cruz: $0.125 \mu \mathrm{g} / \mathrm{mL}$ ); (b) monoclonal mouse anti-human Ki67 (Clone MIB-1: Dakocytomation: $0.8 \mu \mathrm{g} / \mathrm{mL}$ ); (c) polyclonal rabbit anti-CYP11A1 (Merck Millipore: $4 \mu \mathrm{g} / \mathrm{mL}$ ); (d) polyclonal rabbit anti-CYP17A1 (gift: Professor Ian Mason, Edinburgh: $10 \mu \mathrm{g} / \mathrm{mL}$ ). Negative controls comprised incubation with nonspecific mouse, rabbit, or goat IgG. Sections were visualised by incubation with DAB chromagen according to kit instructions (2B Scientific Ltd). The area of cells positively stained for CYP17A1 or CYP11A1 was measured as a percentage of total interstitial area (Image-Pro Plus: Media Cybernetics, Maryland, USA). Twenty randomly selected digital images $(\times 400)$ were analysed by a single observer (BE) while blinded to the group being examined.

Sertoli cell numbers were determined stereologically (Paul et al. 2005, Andrade et al. 2013). In brief, 5- $\mu$ m sections were subjected to immunohistochemistry for AMH. Forty images at $\times 630$ magnification were captured from one testis cross-section using Leica software, ten per pole. Images were overlaid with a 432 point grid (Image-Pro Plus: Media Cybernetics). Sertoli cells across an intersection were counted and this total point value was expressed as a percentage of the maximum count across all 40 images $(40 \times 432=17,280)$. Testis weight occupied by Sertoli cells was calculated (e.g. $1 \mathrm{~g}$ testis with an average point count of $10 \%=0.1 \mathrm{~g}$ of Sertoli cells). A weight-to-volume conversion was applied $\left(1 \mathrm{~g}=1 \mathrm{~cm}^{3}\right)$ to generate the absolute volume (AV) of the testis occupied by Sertoli cells. The average Sertoli cell diameter was measured (Image-pro plus) and the mean nuclear volume (MNV) of each Sertoli cell was determined from the formula $(4 / 3 \pi) r^{3}$. The total number of Sertoli cells per testis was calculated (AV $\left.\left(\mu \mathrm{m}^{3}\right) / \mathrm{MNV}\left(\mu \mathrm{m}^{3}\right)\right)$ and adjusted to account for testis weight.

\section{Measurement of testosterone}

Fetal serum concentrations of total testosterone (bound and unbound) were measured using the automated ADVIA Centaur XP competitive immunoassay system (Siemens Healthcare Diagnostics), as previously reported (Lea et al. 2016). Total serum testosterone assay sensitivity was
$0.35 \mathrm{nmol} / \mathrm{L}$ and the mean intra- and inter-assay $\mathrm{CV}$ values were 4.4 and $6.2 \%$, respectively.

\section{Fetal testicular RNA extraction}

RNA, DNA, and protein were extracted from fetal testis using an AllPrep DNA/RNA/Protein mini kit (Qiagen Ltd.). Samples were homogenised and processed as previously described (Lea et al. 2016). The manufacturer's instructions were followed with the optional on-column DNase digestion included. Samples were homogenised in $600 \mu \mathrm{L}$ RNeasy lysis buffer for tissues (RLT) buffer for $2 \mathrm{~min}$ at $30 \mathrm{~Hz}$, centrifuged after which the lysate was added to an ALLprep DNA column. After centrifugation, the column flow-through was processed by passing through an RNeasy spin column according to kit instructions. In brief, RNA wash buffer (RW1) buffer was centrifuged through the column after which a DNase I incubation mix was added followed by a 15-min incubation at room temperature. The column was then washed/centrifuged with RW1 buffer $(350 \mu \mathrm{L})$ and $2 \times$ RNA purification and elution buffer (RPE) buffer $(500 \mu \mathrm{L})$ after which the addition of $30 \mu \mathrm{L}$ of RNase-free water followed by centrifugation yielded RNA containing flow through for cDNA synthesis.

\section{Customised ovine microarray and pathway analyses}

Transcriptome analysis was conducted using a custom $15 \mathrm{~K}$ Agilent oligo sheep microarray generated as previously described (Lea et al. 2016). In brief, a catalogue Sheep Gene Expression Microarray $8 \times 15 \mathrm{~K}$ (G4813A-019921) was modified by adding new target sequences and removing redundancies. The latter was identified from sheep ESTs assembly and oligo annotations performed by Sigenae (http://www.sigenae.org/). Several different oligonucleotides were used to target sheep contigs, and the best annotated of these at the $3^{\prime}$ end were conserved ( 2 per contig max). Other oligos specific for the same transcript were removed from the array. Agilent 'GE Probe Design' eArray workflow and tools (https://earray.chem.agilent.com/earray/) were used for oligo design. All 1500 new oligos, and those remaining on the original Agilent array, were annotated using Sigenae SigReannot tool49. The array was enriched with genes initially identified in the fetal sheep gonad and completed with control genes known to be expressed in developing fetal gonads from both sexes. The final version of the array comprised 7500 different genes and labelling and hybridisation were performed at the 'Plate-forme Biopuces et Sequencage' (http://wwwmicroarrays.u-strasbg.fr/). Following one-colour labelling and hybridisation using the Quick Amp Labelling kit (Agilent, 51900442) and One- colour RNA Spike-in Kit (Agilent, 5188-5282), arrays were scanned with the Agilent DNA Microarray Scanner Model G2565B. Image analysis was performed with Agilent Feature Extraction software v9.5.3.1.

\section{Gene ontology enrichment}

Identified sheep differentially expressed probes were analysed with Gene Ontology (GO) and Kyoto Encyclopedia of Genes and Genomes (KEGG) pathway membership with Database was performed using the DAVID Bioinformatic Database 6.8 (https://david.ncifcrf.gov/). These analyses and pathways were 
considered significant for a Benjamini corrected enrichment score of less than 0.05. Further analysis of gene pathways utilised the Ingenuity Pathway Analysis software (http://www. ingenu ity.com/). This pathway analysis system uses the same hypergeometric test as DAVID, and topology-based output was used to assess the biological processes impacted by biosolids exposure (Nguyen et al. 2019). We used the eXploring Genomic Relations web tool (http://galahad.well.ox.ac.uk:3040/) under default parameters and with lists of differentially expressed genes tested for enrichment of annotations (Fang et al. 2016).

\section{Pathway and functional analysis of differentially expressed genes (DEGs)}

To further understand biological functions and pathways, sheep differentially expressed transcripts (false discovery rate (FDR) $\leq$ $5 \%$; LogFC threshold \pm 0.2 ) were functionally annotated based on GO terms and KEGG pathway through the DAVID ontology database. Uncharacterized, putative genes and redundant probes were removed so that 1596 (0-80T) and 1567 (0-140T) official gene name symbols were subjected to DAVID analyses. To increase the depth of genes with GO annotations, Homo Sapiens genome annotation was used as background and statistically enriched biological processes and molecular functions were obtained in which the proteins are involved (Ha et al. 2015). The transcripts were classified as: biological process, cellular component, and molecular function. An individual transcript may be represented in several categories.

\section{Validation of transcriptomic data by $q P C R$}

Using the same samples used for microarray, transcript expression was confirmed by real-time PCR (Lea et al. 2016). DNase-treated RNA was used to synthesise cDNA (Transcriptor First Strand cDNA Synthesis Kit: Roche). Standard curves were generated from pooled cDNA (1:5 serial dilutions), and all CDNA samples were diluted at 1:50 in $\mathrm{dH}_{2} \mathrm{O}$. Primers and probes were designed using Primer3 software, and DNA probes were synthesised with a 5'-FAM fluorophore and a 3'-TAMRA quencher (Eurofins, Ebersberg, Germany). Genbank accession numbers and probe and primer sequences are listed in Supplementary Table 1 (see section on supplementary materials given at the end of this article). Samples were run in triplicate using the LightCycler ${ }^{\circledR} 480$ Probes Master (Roche), and 'no template controls' were included as standard. Reaction mixtures and cycling conditions were as previously reported (Lea et al. 2016). All qPCR data were analysed using Roche LightCycler480 software and normalised using the geNorm method. Three housekeeping genes (GAPDH, HPRT, $Y$ WHAZ) were tested for stability using geNorm, Normfinder, and ANOVA analysis.

\section{Statistical analysis}

Morphometric data comprising fetal mass, organ weights (testis, thyroid, adrenal, liver), and AGD were analysed using Generalized Linear Regression (GLR: Genstat statistical package version 20; https://www.vsni.co.uk/). Since males were from singleton and twin pregnancies, data were adjusted for litter size (fixed effects: number of fetuses and treatment, random effect: ewe). The Bonferroni multiple comparisons adjustment was applied, and between-group differences were identified. Sertoli cell numbers and Leydig cell staining were also analysed by GLR. Sertoli and Leydig cell data are presented as scatter plots with means (GraphPad Prism Prism, version 8 ). Fold changes were presented as positive or negative values relative to controls.

For gene array, data processing and analysis were conducted using Biocondutor packages suite (http://www.bioconductor. org/index.html) and LIMMA package50 with the R statistical programme. Raw median signal from Feature Extraction array files was used as non-processed signal and $\log _{2}$ transformed. Background was then subtracted locally, and intra-array normalisation was performed by subtracting the array median signal from each spot signal on the same array. Multiple testing corrections were applied, and differentially expressed transcripts were considered under a FDR of 5\% (Benjamini \& Hochberg 1995).

\section{Results}

\section{Effects of biosolids exposure on the fetal urogenital tract and testosterone}

At day 80 , male fetal mass was not altered by continuous exposure to biosolids and there were no treatment effects on AGD or organ weights (i.e. testis, thyroid, adrenal, and liver: Table 1). In contrast, day 140 male fetuses from ewes exposed from 60 to 140 days of gestation (60-140T group) had a lower fetal mass than non-exposed controls (0-140C), continuously exposed fetuses (0-140T) and fetuses exposed mid-gestation (30-110T) $(P<0.001)$. AGD was shorter in the 60-140T group than controls $(P<0.05)$ (Table 1$)$. The late exposure group (60-140T) also had smaller adrenals $(P<0.05)$, smaller testes $(P<0.001)$, and lower levels of testosterone $(P<0.01)$ compared to control non-exposed fetuses (Table 1 ).

\section{Effects of biosolids exposure on testis development}

Day 80: continuous maternal exposure to biosolids had no effect on $\mathrm{AMH}$-positive Sertoli cell numbers per gram of testis (Fig. 2A and Supplementary Fig. 1A). There was no treatment effect on per cent nucleated area stained for the steroidogenic enzyme CYP11A1 (Fig. 2C and Supplementary Fig. 1C) or CYP17A1 (Fig. 2E and Supplementary Fig. 1D).

Day 140: Sertoli cell numbers per gram of testis were reduced by transient exposure of the mother to biosolids, regardless of when exposure occurred. In contrast, continuous exposure from 0 to 140 days had no effect on Sertoli cell numbers (Fig. 2B) $(P<0.001)$. Positive staining for Ki67 was indicative of Sertoli cell proliferation as expected at this developmental stage (Supplementary Fig. 1B). The per cent testicular area stained for CYP11A1 was reduced in the 0-140T $(P<0.001)$ and $0-80 \mathrm{~T}(P<0.01)$ exposure groups 
Table 1 Morphology (days 80 and 140) and endocrinology (day 140) of male fetuses following exposure to biosolids-treated pastures. Values represent predicted means \pm S.E.M. Experimental groups: $\mathrm{C}=$ control, $\mathrm{T}=$ exposed. Paired organs were combined into a single weight. Data were fitted to a general linear model, adjusting for litter size, and analysed by general linear regression (Genstat). Between-group differences were analysed by Bonferroni (day 140).

\begin{tabular}{|c|c|c|c|c|c|c|c|c|c|}
\hline & \multicolumn{9}{|c|}{ Exposure groups } \\
\hline & \multicolumn{3}{|c|}{ Day 80 fetuses } & \multicolumn{6}{|c|}{ Day 140 fetuses } \\
\hline & $0-80 \mathrm{C}$ & $0-80 \mathrm{~T}$ & $P$ & $0-140 \mathrm{C}$ & $0-140 \mathrm{~T}$ & $0-80 \mathrm{~T}$ & 30-110T & $60-140 \mathrm{~T}$ & $P$ \\
\hline \multicolumn{10}{|l|}{ Morphology } \\
\hline $\begin{array}{l}\text { No. ewes }>1 \text { male } \\
\text { fetus }\left(\mathrm{D} 80^{\mathrm{A}}, \mathrm{D} 140^{\mathrm{B}}\right)\end{array}$ & 8 & 9 & & 11 & 9 & 7 & 8 & 11 & \\
\hline No. fetuses ${ }^{\mathrm{C}}$ & 13 & 11 & & 15 & 12 & 9 & 12 & 15 & \\
\hline $\begin{array}{l}\text { Fetal mass } \\
\quad(\mathrm{g}, \mathrm{D} 80 ; \mathrm{kg} \mathrm{D} 140)\end{array}$ & $346.8 \pm 11.66$ & $318.2 \pm 12.69$ & NS & $5.39 \pm 0.22^{\mathrm{a}}$ & $5.24 \pm 0.26^{\mathrm{a}}$ & $5.01 \pm 0.31^{\mathrm{ab}}$ & $5.32 \pm 0.24^{\mathrm{a}}$ & $4.05 \pm 0.24^{b}$ & $<0.001$ \\
\hline AGD $(\mathrm{mm})$ & $47.07 \pm 0.66$ & $47.77 \pm 0.71$ & NS & $151.6 \pm 3.38^{\mathrm{a}}$ & $144.6 \pm 4.06^{\mathrm{ab}}$ & $150.7 \pm 4.67^{\mathrm{ab}}$ & $142.4 \pm 3.61^{\mathrm{ab}}$ & $134.9 \pm 3.56^{b}$ & $<0.05$ \\
\hline Testis (mg) & $155.7 \pm 9.4$ & $141.4 \pm 10.2$ & NS & $2590 \pm 112.3^{\mathrm{a}}$ & $2534 \pm 128.3^{\mathrm{a}}$ & $2521 \pm 155.5^{\mathrm{a}}$ & $2192 \pm 120.3^{\mathrm{a}}$ & $1677 \pm 118.3^{\mathrm{b}}$ & $<0.001$ \\
\hline Thyroid (mg) & $141.5 \pm 12.84$ & $128.7 \pm 14.0$ & NS & $1370 \pm 107.2$ & $1354 \pm 128.8$ & $1117 \pm 148.0$ & $1249 \pm 119.8$ & $1328 \pm 113.0$ & NS \\
\hline Adrenals (mg) & $126.6 \pm 8.5$ & $132.4 \pm 9.2$ & NS & $647.8 \pm 28.47^{\mathrm{a}}$ & $572.9 \pm 32.53^{\mathrm{ab}}$ & $549.0 . \pm 39.44^{\mathrm{ab}}$ & $591.5 \pm 30.50^{\mathrm{ab}}$ & $505.1 \pm 29.99^{b}$ & $<0.05$ \\
\hline Liver (g) & $21.21 \pm 0.6$ & $19.6 \pm 0.7$ & NS & $132.0 \pm 7.97$ & $130.9 \pm 9.11$ & $134.7 \pm 11.04$ & $149.8 \pm 8.54$ & $117.3 \pm 8.40$ & NS \\
\hline \multicolumn{10}{|l|}{ Fetal endocrinology } \\
\hline Fetal testosterone & & & & $3.60 \pm 0.21^{\mathrm{b}}$ & $3.75 \pm 0.28^{b}$ & $3.45 \pm 0.30^{\mathrm{ab}}$ & $3.52 \pm 0.23^{b}$ & $2.54 \pm 0.23^{\mathrm{a}}$ & $<0.01$ \\
\hline
\end{tabular}

A Ewes at day 80: 82\% (14/17) carried twin pregnancies and the remaining pregnancies were triplets $(n=3)$; ${ }^{\mathrm{B}}$ Ewes at day $140: 69 \%(32 / 46)$ carried twin pregnancies and remaining pregnancies were singles $(n=7)$ and triplets $(n=7)$; ${ }^{C}$ Fetuses were used from all pregnant ewes. Differing superscripts indicate differences between groups and values in bold indicate differences relative to 0-80C or 0-140C. AGD, anogenital distance.

(Fig. 2D), whereas staining for CYP17A1 was reduced in continuous and all transient exposure groups (Fig. 2F).

\section{Effects of biosolids exposure on the testis transcriptome}

Gene array analysis was carried out on three groups of fetuses at 140 days: $0-140 \mathrm{C}, 0-140 \mathrm{~T}$, and 0-80T. Analyses revealed that 249 transcripts $(3.3 \%$ of 7500) were differentially expressed $(P<0.05$ after Benjamini-Hochberg multiple testing correction (FDR at 5\%) and absolute fold change $>1.5$ ) between controls and exposed fetal testes (Fig. 3A). Of these transcripts, 47 were differentially expressed in testes from continuously exposed mothers (0-140T). In contrast, 202 transcripts were differentially expressed in the 0-80T group (Fig. 3A). A total of 22 differentially expressed genes were common to both the $0-80$ and 0-140 exposure groups (Fig. 3B). In the exposure groups, the majority of genes were downregulated, particularly in the 0-80T group (0-80T, 174/202: 86\% vs $0-140$ T, $27 / 47,57 \%$ ) (Fig. $3 \mathrm{~A}$ and Supplementary Table 2). The complete raw data transformed by the platform (processed signal) are provided as Supplementary Table 3.

The functional analysis of differentially expressed transcripts common to both exposure groups highlighted differentially expressed genes associated with VEGF and signalling pathways: SMAD2/3, IGF1, ERK1/ERK2 MAPK, ErbB1,2,3 (Fig. 4). Differentially expressed transcripts specific to the $0-80 \mathrm{~T}$ exposure group were associated with a range of cell specific functions: androgen signalling, angiogenesis, and cell signalling (Fig. 5A). In the lesser perturbed group (0-140T), differentially expressed transcripts were associated with cell signalling, metabolism (e.g. insulin receptor pathway), and angiogenesis (Fig. 5B).

Topological analyses by ingenuity pathway analysis revealed differentially expressed gene networks associated with drug metabolism, disorders of haematological neurological, cardiovascular systems, and metabolic disease (Table 2). High scoring gene networks in the 0-140T group were primarily linked to cell function and these networks were also identified in the 0-80T group (Table 2). Biological functions primarily highlighted in the $0-80 \mathrm{~T}$ group were linked with cancer and reproductive system disease, dermatological disease, and genetic disorders (Table 3 ). The latter two functions were also highlighted in the 0-140T group along with inflammatory disease and skeletal/muscular disorders. Molecular, cellular, and physiological functions in the 0-140T group were low scoring. However, in the 0-80T group, organismal and tissue development along with cell morphology, assembly, and organisation were high-scoring networks (Table 3).

Of the 22 differentially expressed transcripts common to both exposure groups (Fig. 3B), the four most upregulated genes were genes encoding the human leukocyte antigens A and B (Supplementary Table 2: day 80 and day 140 testes, respectively: HLA$A:+1.75$ - and +1.67 -fold change, HLA-B: +1.3 - and +1.6 -fold change). The two most downregulated genes in both groups (0-80T, 0-140T) were POSTN (periostin osteoblast specific factor) and ovin ZFNLOC101104520 (zinc finger protein) (Supplementary Table 2: day 80 and day 140 testes, respectively: POSTN: -1.4and -2.0 -fold change, associated with tumour progression and LOC101104520: $-1.3-$ and -1.2 -fold change, respectively). 

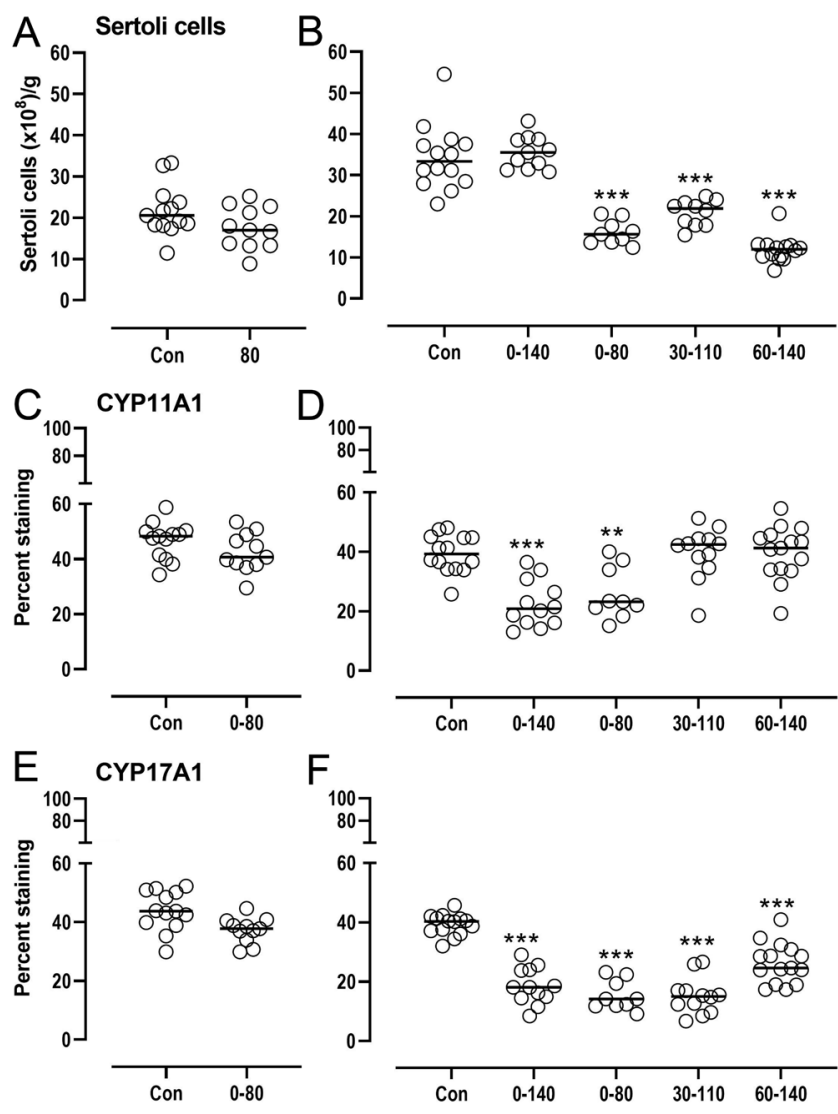

Figure 2 Disturbance in Sertoli cells numbers and area positive for steroidogenic cells in fetal testes following continuous or transient exposure of pregnant ewes to biosolids. Fetal testes were collected at days 80 or day 140 of gestation. Day 80 testes were derived from control (con) non-exposed and continuously exposed mothers. Day 140 testes were derived from control (con) non-exposed mothers, from mothers exposed continuously (0-140) and from mothers exposed for a period of 80 days limited to early (0-80 days), mid (30-110 days), and late gestation (60-140 days). Sertoli cells (A: day 80, B: day 140) were identified by $\mathrm{AMH}$ staining, quantified stereologically, and expressed as numbers per gram of testis. Steroidogenic interstitial cells were identified by immunohistochemistry quantified by image analysis as per cent nucleated interstitial area stained for CYP11A1 (C: day 80, D: day 140) and CYP17A1 (E: day 80, F: day 140). Each symbol corresponds to an individual control or exposed animal. The horizontal line indicates the mean for each group. Day 140 data were fitted to a generalized linear regression model, adjusting for litter size (fixed effects: number of fetuses and treatment, random effect: ewe) (Genstat). Treatment effect: $P<$ 0.001. Between-group differences were analysed by Bonferroni: asterisks indicate significant differences with control non-exposed group.

Confirmation of microarray changes was carried out by $\mathrm{qPCR}$ and comparable exposure-linked changes were observed for POSTN (decreased), MHC class 1 HLA-B (increased), and PTCER3 (marginal decrease) (Supplementary Fig. 2 and Supplementary Table 2).

\section{Discussion}

The current study identifies stages of male fetal gonad development in sheep that are developmentally sensitive to an EC mixture relevant to human exposure. In the current paradigm, exposure occurred when pregnant ewes grazed pastures fertilised with biosolids generated from processed human sewage sludge. Sertoli cell number in day 140 fetuses exposed throughout gestation (0-140 days) remained unchanged but Leydig cell CYP17A1 and CYP11A1 staining was reduced. In contrast, exposure for periods of 80 days limited to early, mid, or late gestation reduced both Sertoli cell numbers and Leydig cell CYP17A1 immuno-reactivity in day 140 male fetal testes, regardless of developmental stage. Of note is that the reduced proportion of interstitial cells positive for CYP17A1 in the 30-110 and 60-140T exposure groups is not reciprocated with CYP11A1. Since fetal testosterone concentrations were reduced only in the 60-140 exposure group, this likely reflects fetal Leydig cell activity and raises the possibility of an exposure-induced reduction in the proportion of CYP17A1-positive testosteronesecreting Leydig cells. Intriguingly, exposure limited to 30-110 days was not sufficient to reduce testosterone but still reduced the proportion of CYP17A1. The lack of an effect on CYP11A1 may reflect differential sensitivity of the steroidogenic enzymes and awaits further characterisation of these cells at this late stage of gestation.

Notably, exposure for the first 80 days of gestation resulted in a dramatic change in the day 140 testis

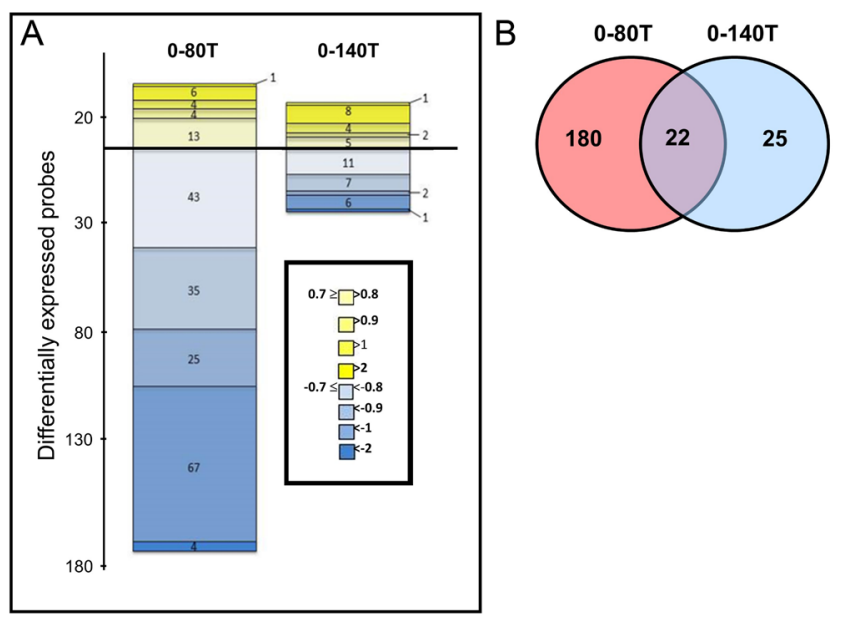

Figure 3 Analysis of differentially expressed (relative to control) fetal testis genes following maternal exposure to biosolids. At day 140, more genes were altered relative to control following biosolids exposure in the 0-80T than in the 0-140T exposure group. (A) Numbers and fold change of differentially expressed genes. Only probes that met an FDR of $5 \%$ and a threshold of \pm 0.7 on the $\log _{2}$ transformed fold change (LogFC) are displayed. Probes are represented according to their positive (yellow) or negative (blue) fold change. (B) Venn diagram showing the number of differentially expressed transcripts unique to and common to both exposure groups. Day 140 testes from 0 to 80 T exposed fetuses had $>8 \times$ the number of differentially expressed transcripts compared to testes from the 0 to $140 \mathrm{~T}$ group. 


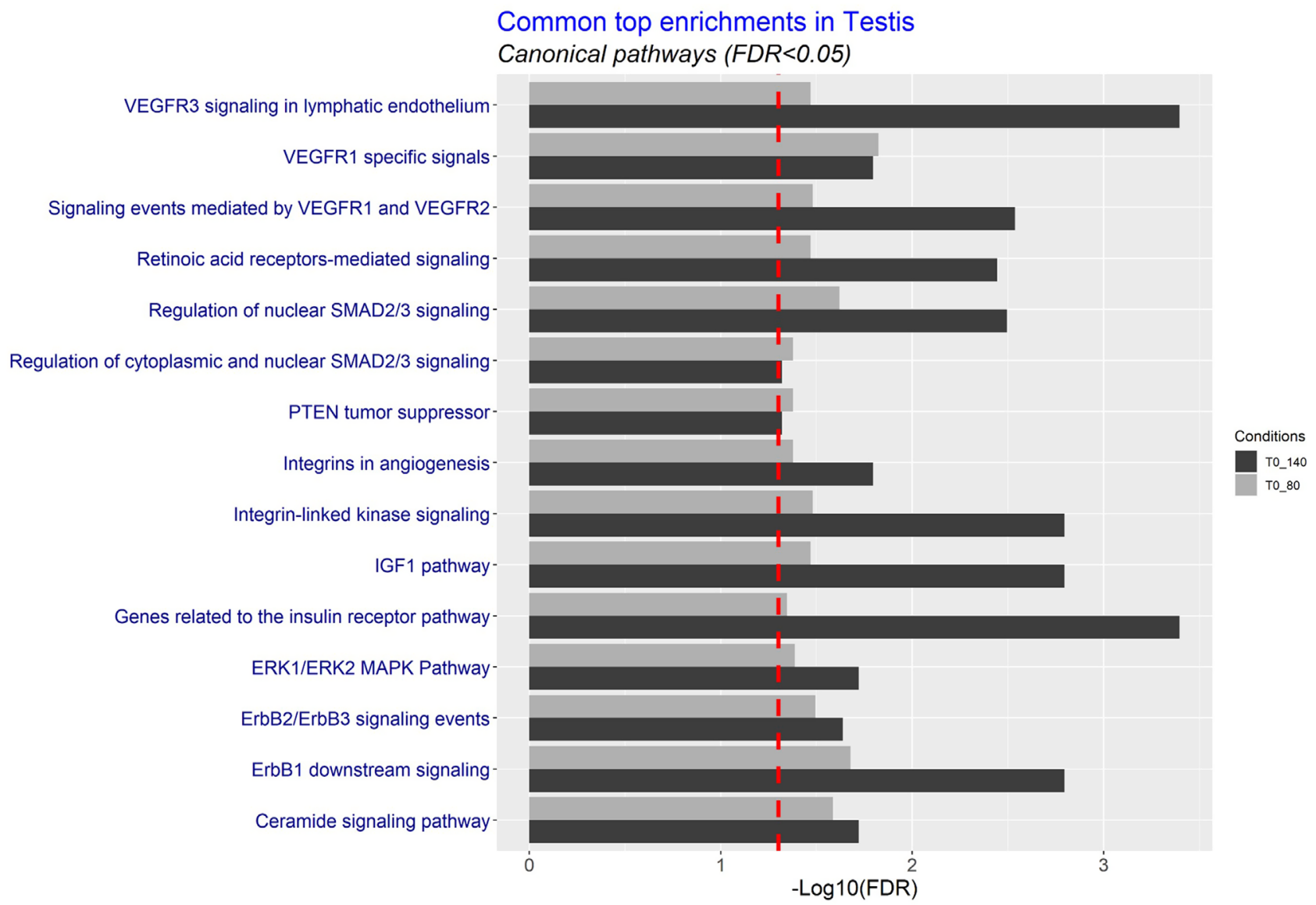

Figure 4 Common canonical testicular pathways following maternal exposure to biosolids in 0-80T and 0-140T groups. Common enrichment probes coding for canonical pathways were analysed using the eXploring Genomic Relations (XGR) web tool.

transcriptome, whereas exposure for the last 80 days induced phenotypic differences manifest by male fetuses with reduced body mass, reduced AGD, smaller testes and adrenals, and reduced fetal testosterone. Indeed, these phenotypic observations are consistent with an anti-androgenic effect on the male fetus (Recabarren et al. 2008, Scully et al. 2018). Taken together, these data indicate that fetal testes transiently exposed to a cocktail of environmental contaminants either do not have time to adapt and/or that exposure alters the cellular composition of the testis between days 80 and 140 . This raises the possibility that the transcriptomic changes observed may reflect some of the cellular changes in transient exposure groups.

\section{Transient vs continuous fetal testis exposure}

Fetuses exposed to ECs for the first 80 days of gestation exhibited a greater change in testis transcriptome than those continuously exposed. Biological consistency can be drawn from similar transcriptomic changes in fetal ovaries examined from the same experimental paradigm. That is, a greater degree of ovarian transcriptomic change was observed in transient vs continuously exposed female fetuses (Lea et al. 2016). Furthermore, relative to animals exposed from mating to 110 days, exposure limited to the pre-conception period reduced the proportion of mid-gestation type 1a ovarian follicles, reduced small blood vessel numbers in the fetal thyroid and specific to the males, increased thyroid organ weights. (Bellingham et al. 2013, HombachKlonisch et al. 2013). It is plausible that in the current study, the lesser degree of testicular transcriptomic change reflects adaptation to a longer and continuous period of exposure with less severe consequences for the fetus. In contrast, altering the environment by moving pregnant ewes from biosolids to control pastures or vice versa requires the fetal testis to adapt at more advanced developmental stages with different longerterm consequences. This applies to all three transient exposure groups (0-80T, 30-110T, 60-140T), and the shorter adaptation period of the 0-80T group may account for the greater phenotypic changes observed at day 140 . Although transcriptomics was not carried out on day 140 fetal testes transiently exposed during mid or late gestation, our observations on Sertoli and Leydig 


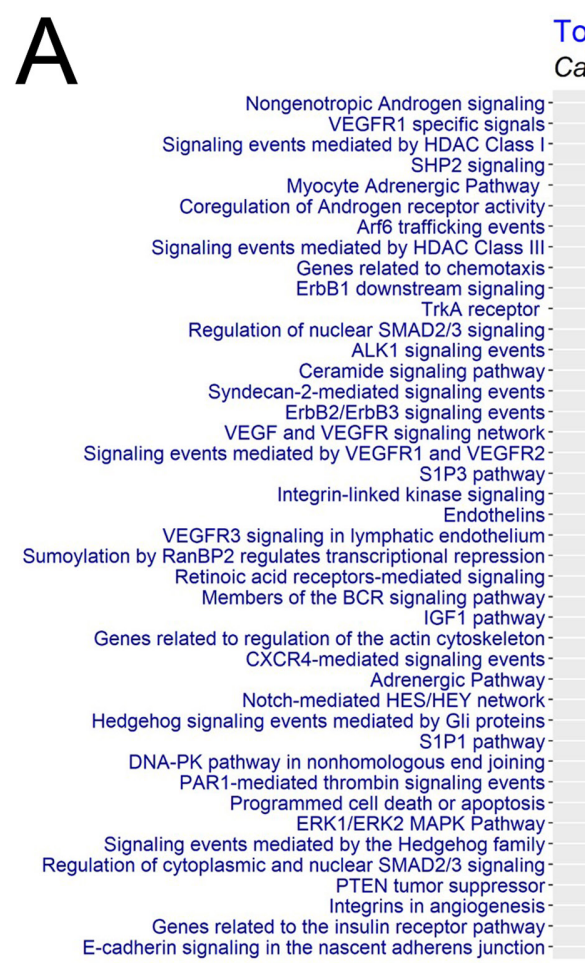

B
Top enrichments 0_80T

Canonical pathways (FDR<0.05)

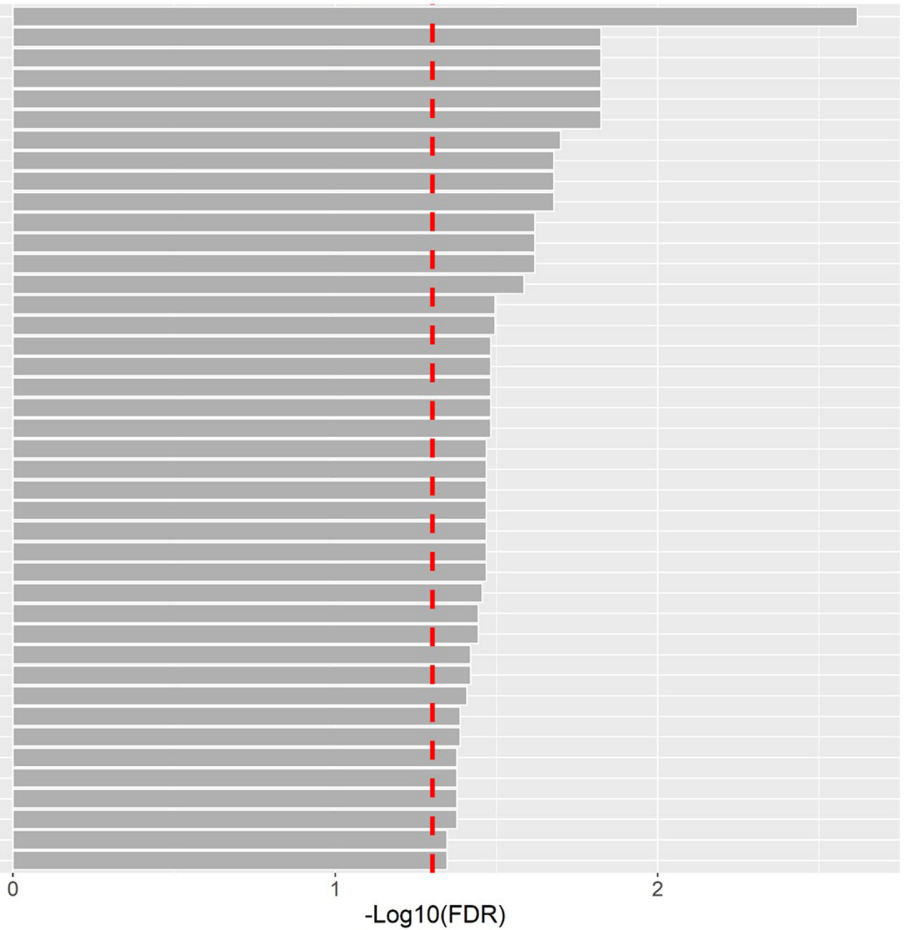

Top enrichments 0_140T

Canonical pathways $(F D R<0.05)$

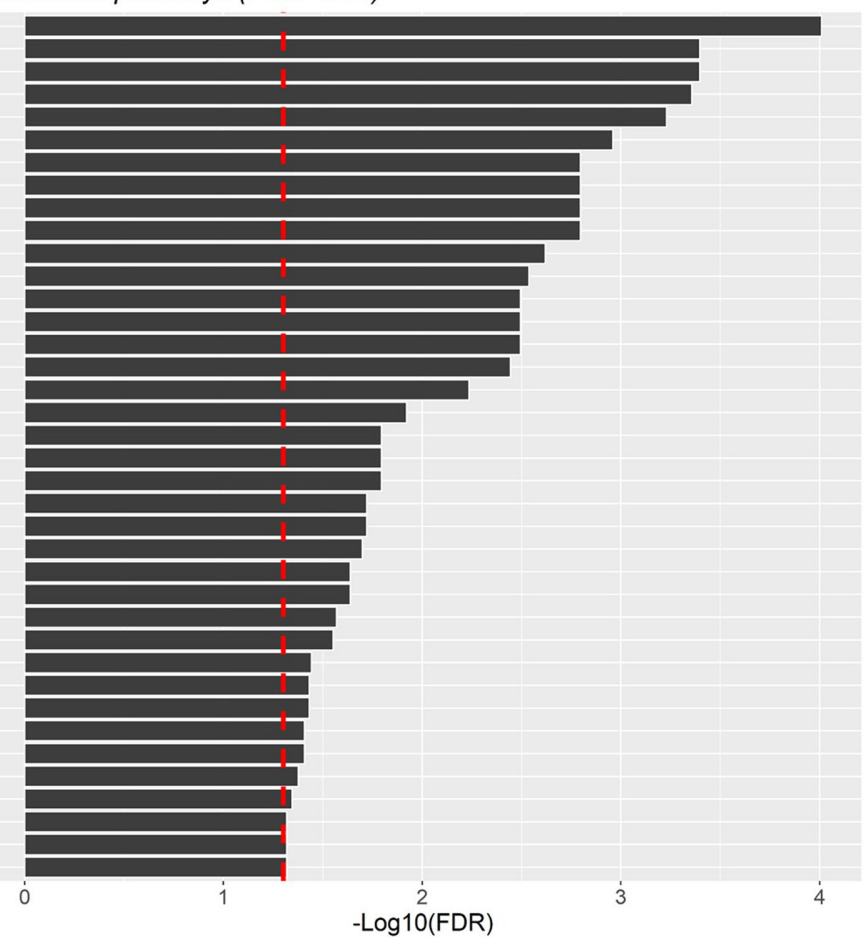

Figure 5 Functional analysis of differentially expressed testis transcripts following maternal exposure to biosolids. Top canonical pathways are shown in (A) 0-80T and (B) 0-140T exposure groups. Analysis was carried out using the eXploring Genomic Relations (XGR) web tool. 
Table 2 Functional analysis of differentially expressed transcripts representative of specific biological pathways.

\begin{tabular}{|c|c|c|}
\hline Treatment group & Associated network functions ${ }^{a}$ & Score \\
\hline $0-80 \mathrm{~T}$ & $\begin{array}{l}\text { 1. Cellular movement, cell morphology, drug metabolism } \\
\text { 2. Cell death, hematological system development and function, cell-mediated immune } \\
\text { response } \\
\text { 3. Cell cycle, hair and skin development and function, connective tissue development and } \\
\text { function. } \\
\text { 4. Developmental disorder, neurological disease, cardiovascular system development and } \\
\text { function } \\
\text { 5. Genetic disorder, metabolic disease, cellular assembly and organisation }\end{array}$ & $\begin{array}{l}44 \\
42 \\
33 \\
27 \\
25\end{array}$ \\
\hline $0-140 \mathrm{~T}$ & $\begin{array}{l}\text { 1. Cell signalling, small molecule biochemistry, inflammatory response } \\
\text { 2. RNA post-transcriptional modification, cell to cell signalling and interaction, cellular } \\
\text { assembly and organisation } \\
\text { 3. Embryonic development, organ development, organismal development } \\
\text { 4. Endocrine system disorders, gastrointestinal disease, genetic disorder } \\
\text { 5. Lipid metabolism, small molecule biochemistry, connective tissue disorders }\end{array}$ & $\begin{array}{r}34 \\
30 \\
3 \\
3 \\
3\end{array}$ \\
\hline
\end{tabular}

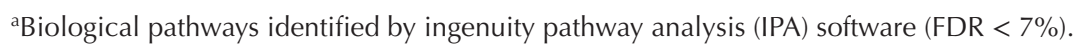

cell markers support this theory. This raises concerns that a transient environmental change during fetal development may adversely affect male reproduction during adulthood, a critically important area not yet explored within the current paradigm.

These data are consistent with three previous studies demonstrating developmental exposure effects on testes from mid-gestation male fetuses, neonatal day 1 males, and post-weaning ram lambs (Paul et al. 2005, Bellingham et al. 2012, Elcombe et al. 2021). Midgestation male fetuses continuously exposed to day
110 exhibited reduced Sertoli and Leydig cell numbers and this was reflected by reduced inhibin $A$ and testosterone. In the current study, the lack of an effect at day 80 likely reflects the earlier developmental stage and/or the shorter period of continuous exposure. In neonatal lambs exposed in utero via the mother, and in adult males exposed via the mother and for a period of 7 months following parturition, testicular abnormalities were observed in a cohort of male offspring, for example fewer germ cells and Sertoli cell-only tubules (Bellingham et al. 2012, Elcombe et al. 2021).

Table 3 Biological functions associated with testicular differentially expressed genes following biosolids exposure.

\begin{tabular}{|c|c|c|c|c|}
\hline \multirow[b]{3}{*}{ Biological functions } & \multicolumn{4}{|c|}{ Treatment groups } \\
\hline & \multicolumn{2}{|l|}{ 0-80T } & \multicolumn{2}{|l|}{ 0-140T } \\
\hline & $P$ & No. mols & $P$ & No. mols \\
\hline \multicolumn{5}{|l|}{ Diseases and disorders } \\
\hline Dermatological disease/conditions & $9.47 \mathrm{E}-04-5.96 \mathrm{E}-03$ & 23 & $3.83 \mathrm{E}-05-4.58 \mathrm{E}-02$ & 8 \\
\hline Genetic disorder & $9.47 \mathrm{E}-04-4.86 \mathrm{E}-02$ & 25 & $9.47 \mathrm{E}-04-5.96 \mathrm{E}-03$ & 23 \\
\hline Cancer & $1.06 \mathrm{E}-04-3.66 \mathrm{E}-02$ & 45 & & \\
\hline Reproductive system disease & $3.83 \mathrm{E}-05-4.67 \mathrm{E}-02$ & 27 & & \\
\hline Gastrointestinal disease & $9.47 \mathrm{E}-04-4.95 \mathrm{E}-02$ & 11 & & \\
\hline Connective tissue disorders & & & $3.83 \mathrm{E}-05-4.67 \mathrm{E}-02$ & 3 \\
\hline Inflammatory disease & & & $9.47 \mathrm{E}-04-4.86 \mathrm{E}-02$ & 13 \\
\hline Skeletal and muscular disorders & & & $9.47 \mathrm{E}-04-4.95 \mathrm{E}-02$ & 12 \\
\hline \multicolumn{5}{|l|}{ Molecular and cell functions } \\
\hline Cell morphology & $1.75 \mathrm{E}-04-3.01 \mathrm{E}-02$ & 20 & $1.16 \mathrm{E}-03-4.48 \mathrm{E}-02$ & 9 \\
\hline Cell assembly and organisation & $3.24 \mathrm{E}-04-3.66 \mathrm{E}-02$ & 29 & & \\
\hline Cellular compromise & $3.24 \mathrm{E}-04-3.66 \mathrm{E}-02$ & 9 & & \\
\hline Lipid metabolism & $5.38 \mathrm{E}-04-3.38 \mathrm{E}-02$ & 8 & & \\
\hline Molecular transport & $5.38 \mathrm{E}-04-3.66 \mathrm{E}-02$ & 12 & & \\
\hline Gene expression & & & $4.53 \mathrm{E}-04-4.10 \mathrm{E}-02$ & 3 \\
\hline Cell function and maintenance & & & $8.66 \mathrm{E}-04-4.29 \mathrm{E}-02$ & 8 \\
\hline Cell death & & & $1.12 \mathrm{E}-03-4.67 \mathrm{E}-02$ & 8 \\
\hline Cellular movement & & & $1.41 \mathrm{E}-03-4.48 \mathrm{E}-02$ & 6 \\
\hline \multicolumn{5}{|c|}{ Phyiological system development and function } \\
\hline Organismal development & $2.62 \mathrm{E}-04-3.66 \mathrm{E}-02$ & 37 & $1.12 \mathrm{E}-03-3.72 \mathrm{E}-02$ & 8 \\
\hline Cardiovascular system & $1.30 \mathrm{E}-03-2.93 \mathrm{E}-02$ & 14 & $1.84 \mathrm{E}-03-3.72 \mathrm{E}-02$ & 5 \\
\hline Tissue development & $8.03 \mathrm{E}-04-3.66 \mathrm{E}-02$ & 34 & & \\
\hline Hair and skin & $1.54 \mathrm{E}-03-3.10 \mathrm{E}-02$ & 10 & & \\
\hline Renal and urological & $1.81 \mathrm{E}-03-3.66 \mathrm{E}-02$ & 13 & & \\
\hline Reproductive system & & & $3.97 \mathrm{E}-04-2.56 \mathrm{E}-02$ & 6 \\
\hline Organ development & & & $1.84 \mathrm{E}-03-1.19 \mathrm{E}-02$ & 4 \\
\hline Visual system & & & $1.84 \mathrm{E}-03-1.99 \mathrm{E}-03$ & 3 \\
\hline
\end{tabular}




\section{Anti-androgenic effects}

Our observations of reduced fetal AGD and impaired testis development support studies linking these observations with chemical exposures during fetal developmental (Gray et al. 2006). Furthermore, a common masculinisation programming period has been identified in rats that occurs just after testis differentiation (Welsh et al. 2008). During this period, exposure to an androgenic chemical reduces AGD concomitantly with the induction of hypospadias and cryptorchidism. In developing male fetal sheep, prenatal androgen exposure mid-gestation also alters gonadal development although an increase in AGD has been reported (Manikkam et al. 2004, Padmanabhan et al. 2010). Notably, we have previously reported that female fetuses exposed to biosolids via the mother have an increased AGD and postulated that this may be androgenic (Lea et al. 2016, Dorman et al. 2018). In the current study, the reduction in AGD was specific to smaller male fetuses and this effect characterised only the late gestation exposure group. However, the fact that CYP17A1 and testosterone were significantly reduced and other organ weights (e.g. thyroid) were not affected in this group argues for a dysregulation of androgen production and target tissue response, probably exacerbated by the concomitant reduced growth. An increased risk of urogenital defects, like hypospadias, is associated with small for gestational age in humans and this is associated with altered placental androgen production ( $\mathrm{O}^{\prime}$ Shaughnessy et al. 2019). This raises the possibility that biosolids chemicals may disturb placental function/androgen production, leading to an increased risk of impaired masculinisation.

Importantly, during fetal life and after the proliferation of germ cells, the stages of development between the testis and ovary are fundamentally different. In the ovine (and human) ovary, two essential steps take place: meiosis initiation and blockage of the oocyte at the end of prophase I and follicle formation (Mandon-Pepin et al. 2003). In the testis, germ cells remain quiescent until puberty. Despite this observation, female fetuses had greater sensitivity to exposure during mid and late gestation rather than in early gestation as described for the males. This may reflect the earlier rate of development of the testis compared to the ovary (Smith et al. 2014, Wilhelm et al. 2007) and/or the differential sensitivity of the testis and ovary to specific chemical types. Of note is that maternal liver phthalate was increased specifically in the 0-80T group while specific changes in liver PCBs and PBDEs characterised the mid and late gestation groups (Lea et al. 2016).

\section{Transcriptomic analyses}

Although direct causality cannot be established, the combined chemical measurements and transcriptomic studies suggest that the developing gonad is less well-equipped to respond to a transient change in environment, than to a consistent but abnormal change. In the current study, transcriptomic analyses highlighted drug metabolism as a key function of the differentially expressed genes in the 0-80T group but not the 0-140T group. Drug-metabolising enzymes such as the differentially expressed gonadal P450 (CYP) family genes reported in the current study are also reported to show altered expression during development (Hines 2008). We therefore propose that this may account for some of the differences between exposure groups. Also unique to this group were gene networks associated with development or disorders in a range of key body systems including haematological, connective tissue, neurological, cardiovascular, and metabolism. In contrast, high scoring networks in the 0-140T group were primarily linked to cell functions: signalling, interaction, assembly, and organisation, and these were also highlighted in the 0-80T group. Notably, our previous transcriptomic studies of biosolids-exposed fetal ovaries indicated that genes linked to drug metabolism were altered in the most perturbed 60-140T group (Lea et al. 2016). We postulated that activation of these genes following intermittent exposure of the fetus may impact later development and that this may account for the greater effect of transient exposures to biosolids. This raises the possibility that this may also apply to the developing male.

In the 0-80T group, the transcriptional regulator SOHLH1, associated with early spermatogonia differentiation and subsequent male fertility, was a top upregulated gene (Toyoda et al. 2014). In mice, SOHLH1 is expressed in gonadal germ cells (fetal and post-natal) and is crucial for germ cell survival and spermatogenesis (Barrios et al. 2012). The dysregulation of SOHLH1 may be associated with the altered androgen regulation of Sertoli cells and thus germ cell development. Furthermore, altered SOHLH1 may also be indirectly linked to exposure-induced changes in testicular drug metabolisms pathways. These areas constitute lines of further investigation.

The upregulation of HLA antigens in both exposure groups and the testicular cell-mediated/inflammatory gene networks identified may reflect exposure-induced changes in immune function (Bansal et al. 2018). Since immunological competence in fetal lambs develops progressively throughout gestation (Nalubamba et al. 2008), markers such as pattern recognition receptors (TLR10) and chemokine receptors (CXCR5) provide potential follow-up genes for further investigation. For both exposure groups, RXR function and PPAR $\alpha$ activation constituted the top toxicological network. The PPAR receptors, including PPAR $\propto$ (NR1C1), are expressed in mammalian fetal testis (Froment et al. 2006) and the alpha form is implicated in Sertoli cell metabolism (Rouiller-Fabre et al. 2015). Since maternal liver phthalate levels were increased in the 0-80T group 
and rodent studies indicate phthalate toxicity effects on the testis are partly mediated by PPAR and RXR, phthalates may contribute to the effects of biosolids on the male ovine fetus (Ward et al. 1998, Ryu et al. 2008, Lea et al. 2016).

Androgen signalling was perturbed in the 0-80T group (DAVID) and this is consistent with the phenotypic effects observed in exposed male (reduced AGD, lowered testosterone, reduced fetal body, adrenal and testis mass) and female fetuses (e.g. increased AGD, increased testosterone, reduced fetal and uterus mass) (Lea et al. 2016). Angiogenic factors were also differentially affected across the two treated male groups along with classical cell signalling systems: retinoic acid, SMAD2/3, IGF1, ERK1/2/MAPK, and ErB1. The trend for downregulation of differentially expressed fetal testicular transcripts in the 0-80T group parallels the downregulation of fetal ovarian transcripts in fetuses from the same experiment (Lea et al. 2016). This may be reflective of an underlying epigenetic mechanism in both sexes. Interestingly, histone deacetylase signalling was altered in the 0-80T males, and in our previous study of the females, histone methylation genes were altered

\section{Conclusions}

In conclusion, the data presented in this study demonstrate that the ovine fetal testis exhibits differential and temporal sensitivity to chemical mixtures present in pastures treated with biosolids fertiliser. We have demonstrated, for the first time, that a short period of environmental exposure applied for the first 80 days of gestation dramatically alters the fetal testis transcriptome at day 140 . Furthermore, restricting the period of environmental change to the final 80 days of gestation induces phenotypic changes indicative of an antiandrogenic effect on the male fetus. Relative to the shorter periods of biosolids exposure, continuous exposure was associated with fewer differentially regulated genes and a lesser effect on the male phenotype (fetal, adrenal, testis mass, AGD, and fetal testosterone unaltered), we propose that a short period of exposure either does not allow the developing fetus to adapt and/or alters the cellular composition of the testis. Collectively, these data indicate that exposure of grazing ruminants to mixtures of chemicals contained in biosolids fertiliser may be linked to perturbations in testicular development. Given the relevance of the biosolids model to human exposures and the consumption of ruminant-derived food products, these data should be viewed as a concern for animal and human male reproductive health.

\section{Supplementary materials}

This is linked to the online version of the paper at https://doi. org/10.1530/REP-21-0235.

\section{Declaration of interest}

The authors declare that there is no conflict of interest that could be perceived as prejudicing the impartiality of the research reported.

\section{Funding}

This work was supported by the European Commission Framework 7 Programme (Contract No. 212885) and by the National Institutes of Health (grant number R01 ES030374).

\section{Author contribution statement}

R G L, C C, P A F, and K D S conceived of and designed the study. B F E and A B carried out the histological studies and testicular cell counts. C C, B M P, B L, E P, and L J designed and analysed the microarray results. L P, B M P, and R G L carried out all qPCR studies and analyses. Z Z carried out all chemical analyses and academic input in interpreting chemical effects. R G L and K D S wrote the paper. P A F co-ordinated the REEF EU FP7 project which funded the work and R G L, K D S, and C C were work-package leaders.

\section{Acknowledgements}

The authors thank George Corsar and Jim MacDonald for the management of experimental animals.

\section{References}

Andrade LP, Rhind SM, Rae MT, Kyle CE, Jowett J \& Lea RG 2013 Maternal undernutrition does not alter Sertoli cell numbers or the expression of key developmental markers in the mid-gestation ovine fetal testis. Journal of Negative Results in Biomedicine 12 2. (https://doi.org/10.1186/14775751-12-2)

Bansal A, Henao-Mejia J \& Simmons RA 2018 Immune system: an emerging player in mediating effects of endocrine disruptors on metabolic health. Endocrinology 159 32-45. (https://doi.org/10.1210/ en.2017-00882)

Barrios F, Filipponi D, Campolo F, Gori M, Bramucci F, Pellegrini M, Ottolenghi S, Rossi P, Jannini EA \& Dolci S 2012 SOHLH1 and SOHLH2 control kit expression during postnatal male germ cell development. Journal of Cell Science 125 1455-1464. (https://doi.org/10.1242/ jcs.092593)

Bellingham M, Fowler PA, Amezaga MR, Rhind SM, Cotinot C, MandonPepin B, Sharpe RM \& Evans NP 2009 Exposure to a complex cocktail of environmental endocrine-disrupting compounds disturbs the kisspeptin/GPR54 system in ovine hypothalamus and pituitary gland. Environmental Health Perspectives 117 1556-1562. (https://doi. org/10.1289/ehp.0900699)

Bellingham M, Fowler PA, Amezaga MR, Whitelaw CM, Rhind SM, Cotinot C, Mandon-Pepin B, Sharpe RM \& Evans NP 2010 Foetal hypothalamic and pituitary expression of gonadotrophin-releasing hormone and galanin systems is disturbed by exposure to sewage sludge chemicals via maternal ingestion. Journal of Neuroendocrinology 22 527-533. (https://doi.org/10.1111/j.1365-2826.2010.01974.x)

Bellingham M, McKinnell C, Fowler PA, Amezaga MR, Zhang Z, Rhind SM, Cotinot C, Mandon-Pepin B, Evans NP \& Sharpe RM 2012 Foetal and post-natal exposure of sheep to sewage sludge chemicals disrupts sperm production in adulthood in a subset of animals. International Journal of Andrology 35 317-329. (https://doi.org/10.1111/j.13652605.2011.01234.x) 
Bellingham M, Amezaga MR, Mandon-Pepin B, Speers CJ, Kyle CE, Evans NP, Sharpe RM, Cotinot C, Rhind SM \& Fowler PA 2013 Exposure to chemical cocktails before or after conception - the effect of timing on ovarian development. Molecular and Cellular Endocrinology 376 156-172. (https://doi.org/10.1016/j.mce.2013.06.016)

Benjamini Y \& Hochberg Y 1995 Controlling the false discovery rate: a practical and powerful approach to multiple testing. Journal of the Royal Statistical Society: Series B 57 289-300. (https://doi. org/10.1111/j.2517-6161.1995.tb02031.x)

Carlsen E, Giwercman A, Keiding N \& Skakkebaek NE 1992 Evidence for decreasing quality of semen during past 50 years. BMJ 305 609-613. (https://doi.org/10.1136/bmj.305.6854.609)

Dorman DC, Chiu W, Hales BF, Hauser R, Johnson KJ, Mantus E, Martel S, Robinson KA, Rooney AA, Rudel $\mathbf{R}$ et al. 2018 Systematic reviews and meta-analyses of human and animal evidence of prenatal diethylhexyl phthalate exposure and changes in male anogenital distance. Journal of Toxicology and Environmental Health: Part B, Critical Reviews 21 207-226. (https://doi.org/10.1080/10937404.2018.1505354)

Elcombe CS, Monteiro A, Ghasemzadeh-Hasankolaei M, Evans NP \& Bellingham M 2021 Morphological and transcriptomic alterations in neonatal lamb testes following developmental exposure to lowlevel environmental chemical mixture. Environmental Toxicology and Pharmacology 86 103670. (https://doi.org/10.1016/j.etap.2021.103670)

Fang H, Knezevic B, Burnham KL \& Knight JC 2016 XGR software for enhanced interpretation of genomic summary data, illustrated by application to immunological traits. Genome Medicine 8 129. (https:// doi.org/10.1186/s13073-016-0384-y)

Filis P, Walker N, Robertson L, Eaton-Turner E, Ramona L, Bellingham M, Amezaga MR, Zhang Z, Mandon-Pepin B, Evans NP et al. 2019 Longterm exposure to chemicals in sewage sludge fertilizer alters liver lipid content in females and cancer marker expression in males. Environment International 124 98-108. (https://doi.org/10.1016/j.envint.2019.01.003)

Fowler PA, Dora NJ, McFerran H, Amezaga MR, Miller DW, Lea RG, Cash P, McNeilly AS, Evans NP, Cotinot C et al. 2008 In utero exposure to low doses of environmental pollutants disrupts fetal ovarian development in sheep. Molecular Human Reproduction 14 269-280. (https://doi.org/10.1093/molehr/gan020)

Froment P, Gizard F, Defever D, Staels B, Dupont J \& Monget P 2006 Peroxisome proliferator-activated receptors in reproductive tissues: from gametogenesis to parturition. Journal of Endocrinology 189 199-209. (https://doi.org/10.1677/joe.1.06667)

Gray Jr LE, Wilson VS, Stoker T, Lambright C, Furr J, Noriega N, Howdeshell K, Ankley GT \& Guillette L 2006 Adverse effects of environmental antiandrogens and androgens on reproductive development in mammals. International Journal of Andrology 29 96-104; discussion 105-108. (https://doi.org/10.1111/j.13652605.2005.00636.x)

Ha M, Sabherwal M, Duncan E, Stevens S, Stockwell P, McConnell M, Bekhit Ael Ael-D \& Carne A 2015 In-depth characterization of sheep (Ovis aries) milk whey proteome and comparison with cow (Bos taurus). PLOS ONE 10 e0139774. (https://doi.org/10.1371/journal. pone.0139774)

Hines RN 2008 The ontogeny of drug metabolism enzymes and implications for adverse drug events. Pharmacology and Therapeutics 118 250-267. (https://doi.org/10.1016/j.pharmthera.2008.02.005)

Hochereau-de Reviers MT, Perreau C, Pisselet C, Locatelli A \& Bosc M 1995 Ontogenesis of somatic and germ cells in sheep fetal testis. Journal of Reproduction and Fertility 103 41-46. (https://doi.org/10.1530/ jrf.0.1030041)

Hombach-Klonisch S, Danescu A, Begum F, Amezaga MR, Rhind SM, Sharpe RM, Evans NP, Bellingham M, Cotinot C, Mandon-Pepin B et al. 2013 Peri-conceptional changes in maternal exposure to sewage sludge chemicals disturbs fetal thyroid gland development in sheep. Molecular and Cellular Endocrinology 367 98-108. (https://doi.org/10.1016/j. mce.2012.12.022)

Istvan M, Rahban R, Dananche B, Senn A, Stettler E, Multigner L, Nef S \& Garlantezec R 2021 Maternal occupational exposure to endocrinedisrupting chemicals during pregnancy and semen parameters in adulthood: results of a nationwide cross-sectional study among Swiss conscripts. Human Reproduction 36 1948-1958. (https://doi. org/10.1093/humrep/deab034)

Landrigan PJ 2017 Air pollution and health. Lancet Public Health 2 e4-e5. (https://doi.org/10.1016/S2468-2667(16)30023-8)
Lea RG, Amezaga MR, Loup B, Mandon-Pepin B, Stefansdottir A, Filis P, Kyle C, Zhang Z, Allen C, Purdie L et al. 2016 The fetal ovary exhibits temporal sensitivity to a 'real-life' mixture of environmental chemicals. Scientific Reports 6 22279. (https://doi.org/10.1038/srep22279)

Levine $H$, Jorgensen $N$, Martino-Andrade A, Mendiola J, WekslerDerri D, Mindlis I, Pinotti R \& Swan SH 2017 Temporal trends in sperm count: a systematic review and meta-regression analysis. Human Reproduction Update 23 646-659. (https://doi.org/10.1093/humupd/ dmx022)

Mandon-Pepin B, Oustry-Vaiman A, Vigier B, Piumi F, Cribiu E \& Cotinot C 2003 Expression profiles and chromosomal localization of genes controlling meiosis and follicular development in the sheep ovary. Biology of Reproduction 68 985-995. (https://doi.org/10.1095/ biolreprod.102.008557)

Manikkam M, Crespi EJ, Doop DD, Herkimer C, Lee JS, Yu S, Brown MB, Foster DL \& Padmanabhan V 2004 Fetal programming: prenatal testosterone excess leads to fetal growth retardation and postnatal catch-up growth in sheep. Endocrinology 145 790-798. (https://doi. org/10.1210/en.2003-0478)

Mesiano S, Hart CS, Heyer BW, Kaplan SL \& Grumbach MM 1991 Hormone ontogeny in the ovine fetus. XXVI. A sex difference in the effect of castration on the hypothalamic-pituitary gonadotropin unit in the ovine fetus. Endocrinology 129 3073-3079. (https://doi.org/10.1210/ endo-129-6-3073)

Nalubamba KS, Gossner AG, Dalziel RG \& Hopkins J 2008 Differential expression of pattern recognition receptors during the development of foetal sheep. Developmental and Comparative Immunology 32 869-874. (https://doi.org/10.1016/j.dci.2007.12.007)

Nguyen TM, Shafi A, Nguyen T \& Draghici S 2019 Identifying significantly impacted pathways: a comprehensive review and assessment. Genome Biology 20 203. (https://doi.org/10.1186/s13059-019-1790-4)

O'Shaughnessy PJ, Antignac JP, Le Bizec B, Morvan ML, Svechnikov K, Soder O, Savchuk I, Monteiro A, Soffientini U, Johnston ZC et al. 2019 Alternative (backdoor) androgen production and masculinization in the human fetus. PLoS Biology 17 e3000002. (https://doi.org/10.1371/ journal.pbio.3000002)

Padmanabhan V, Sarma HN, Savabieasfahani M, Steckler TL \& VeigaLopez A 2010 Developmental reprogramming of reproductive and metabolic dysfunction in sheep: native steroids vs. environmental steroid receptor modulators. International Journal of Andrology 33 394-404. (https://doi.org/10.1111/j.1365-2605.2009.01024.x)

Park JS, Kim J, Elghiaty A \& Ham WS 2018 Recent global trends in testicular cancer incidence and mortality. Medicine 97 e12390. (https:// doi.org/10.1097/MD.0000000000012390)

Paul C, Rhind SM, Kyle CE, Scott H, McKinnell C \& Sharpe RM 2005 Cellular and hormonal disruption of fetal testis development in sheep reared on pasture treated with sewage sludge. Environmental Health Perspectives 113 1580-1587. (https://doi.org/10.1289/ehp.8028)

Pomerantz DK \& Nalbandov AV 1975 Androgen level in the sheep fetus during gestation. Proceedings of the Society for Experimental Biology and Medicine 149 413-416. (https://doi.org/10.3181/00379727149-38818)

Quirke LD, Juengel JL, Tisdall DJ, Lun S, Heath DA \& McNatty KP 2001 Ontogeny of steroidogenesis in the fetal sheep gonad. Biology of Reproduction 65 216-228. (https://doi.org/10.1095/biolreprod65.1.216)

Recabarren SE, Rojas-Garcia PP, Recabarren MP, Alfaro VH, Smith R, Padmanabhan V \& Sir-Petermann T 2008 Prenatal testosterone excess reduces sperm count and motility. Endocrinology 149 6444-6448. (https://doi.org/10.1210/en.2008-0785)

Roselli CE, Amodei R, Gribbin KP, Corder K, Stormshak F \& Estill CT 2016 Excess testosterone exposure alters hypothalamic-pituitary-testicular axis dynamics and gene expression in sheep fetuses. Endocrinology 157 4234-4245. (https://doi.org/10.1210/en.2016-1411)

Rouiller-Fabre V, Guerquin MJ, N'Tumba-Byn T, Muczynski V, Moison D, Tourpin S, Messiaen S, Habert R \& Livera G 2015 Nuclear receptors and endocrine disruptors in fetal and neonatal testes: a gapped landscape. Frontiers in Endocrinology 6 58. (https://doi.org/10.3389/ fendo.2015.00058)

Ryu JY, Lee E, Kim TH, Lee YJ, Lee J, Lee BM, Kwack SJ, Jung KK, Han SY, Kim SH et al. 2008 Time-response effects of testicular gene expression profiles in Sprague-Dawley male rats treated with di(n-butyl) phthalate. Journal of Toxicology and Environmental Health: Part A 71 1542-1549. (https://doi.org/10.1080/15287390802391992) 
Salian S, Doshi T \& Vanage G 2011 Perinatal exposure of rats to bisphenol A affects fertility of male offspring - an overview. Reproductive Toxicology 31 359-362. (https://doi.org/10.1016/j.reprotox.2010.10.008)

Scully CM, Estill CT, Amodei R, McKune A, Gribbin KP, Meaker M, Stormshak F \& Roselli CE 2018 Early prenatal androgen exposure reduces testes size and sperm concentration in sheep without altering neuroendocrine differentiation and masculine sexual behavior. Domestic Animal Endocrinology 62 1-9. (https://doi.org/10.1016/j. domaniend.2017.07.001)

Skakkebaek NE, Rajpert-De Meyts E \& Main KM 2001 Testicular dysgenesis syndrome: an increasingly common developmental disorder with environmental aspects. Human Reproduction 16 972-978. (https://doi. org/10.1093/humrep/16.5.972)

Skakkebaek NE, Rajpert-De Meyts E, Buck Louis GM, Toppari J, Andersson AM, Eisenberg ML, Jensen TK, Jorgensen N, Swan $\mathbf{S H}$, Sapra KJ et al. 2016 Male reproductive disorders and fertility trends: influences of environment and genetic susceptibility. Physiological Reviews 96 55-97. (https://doi.org/10.1152/physrev.00017.2015)

Smith P, Wilhelm D \& Rodgers RJ 2014 Development of mammalian ovary. Journal of Endocrinology 221 R145-R161. (https://doi.org/10.1530/JOE14-0062)

Sumner RN, Harris IT, Van der Mescht M, Byers A, England GCW \& Lea RG 2020 The dog as a sentinel species for environmental effects on human fertility. Reproduction 159 R265-R276. (https://doi.org/10.1530/ REP-20-0042)

Swan SH, Elkin EP \& Fenster L 2000 The question of declining sperm density revisited: an analysis of 101 studies published 1934-1996. Environmental Health Perspectives 108 961-966. (https://doi.org/10.1289/ehp.00108961)

Toyoda S, Yoshimura T, Mizuta J \& Miyazaki J 2014 Auto-regulation of the Sohlh1 gene by the SOHLH2/SOHLH1/SP1 complex: implications for early spermatogenesis and oogenesis. PLOS ONE 9 e101681. (https://doi org/10.1371/journal.pone.0101681)
Viguie C, Chaillou E, Gayrard V, Picard-Hagen N \& Fowler PA 2020 Toward a better understanding of the effects of endocrine disrupting compounds on health: human-relevant case studies from sheep models. Molecular and Cellular Endocrinology 505 110711. (https://doi.org/10.1016/j. mce.2020.110711)

Ward JM, Peters JM, Perella CM \& Gonzalez FJ 1998 Receptor and nonreceptor-mediated organ-specific toxicity of di(2-ethylhexyl) phthalate (DEHP) in peroxisome proliferator-activated receptor alpha-null mice. Toxicologic Pathology 26 240-246. (https://doi. org/10.1177/019262339802600208)

Welsh M, Saunders PT, Fisken M, Scott HM, Hutchison GR, Smith LB \& Sharpe RM 2008 Identification in rats of a programming window for reproductive tract masculinization, disruption of which leads to hypospadias and cryptorchidism. Journal of Clinical Investigation 118 1479-1490. (https://doi.org/10.1172/JCl34241)

Wilhelm D, Palmer S \& Koopman P 2007 Sex determination and gonadal development in mammals. Physiological Reviews 87 1-28. (https://doi. org/10.1152/physrev.00009.2006)

Wohlfahrt-Veje C, Main KM \& Skakkebaek NE 2009 Testicular dysgenesis syndrome: foetal origin of adult reproductive problems. Clinical Endocrinology 71 459-465. (https://doi.org/10.1111/j.13652265.2009.03545.x)

Received 3 June 2021

First decision 25 June 2021

Revised manuscript received 16 December 2021

Accepted 11 January 2022 